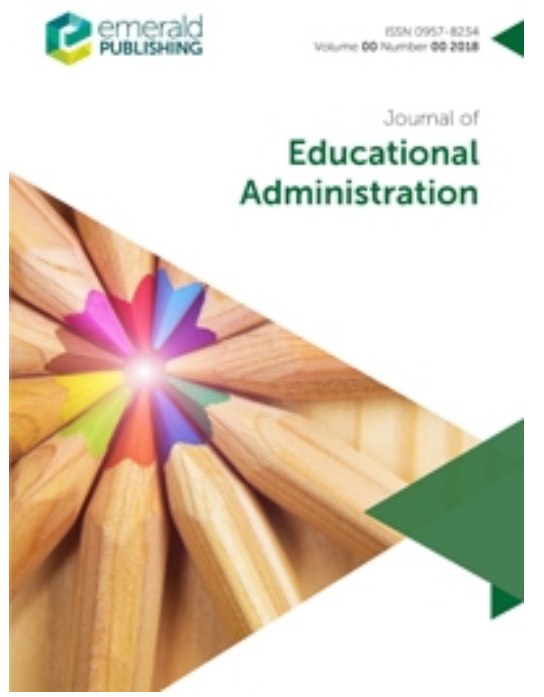

\title{
Promoting collaboration in a competitive context: school improvement networks in Chile
}

\begin{tabular}{|r|l|}
\hline Journal: & Journal of Educational Administration \\
\hline Manuscript ID & JEA-11-2018-0213.R4 \\
\hline Manuscript Type: & Research Paper (Quantitative) \\
\hline Keywords: & $\begin{array}{l}\text { Collaboration, Networked Improvement, School Networks, Professional } \\
\text { Capital, School Improvement }\end{array}$ \\
\hline \multicolumn{2}{|l}{} \\
\hline
\end{tabular}

\section{SCHOLARONE ${ }^{m}$ \\ Manuscripts}




\title{
Promoting collaboration in a competitive context: school improvement networks in Chile
}

\begin{abstract}
Purpose - Chile has developed the School Improvement Networks (SINs) strategy to support the work of school leaders. This paper analyzes the functioning and effect of the SINs strategy as perceived by principals and curriculum coordinators across the country.

Design/methodology/approach - An adapted version of the Educational Collaborative Network Questionnaire (ECN-Q) was applied to a sample of 1,723 participants from 1,375 schools distributed in 398 networks. Descriptive, factor and sub-group statistical analyzes by school performance categories and by different roles within these schools and networks are presented.

Findings - Results indicate that school leaders perceive SINs as an opportunity to work effectively in shared projects that can later be implemented in their own schools. Participants indicate that they can share knowledge in their networks and use it to solve problems in their own schools, which is especially relevant for secondary school leaders that work in difficult circumstances. Results suggest that it is important to facilitate greater autonomy for school leaders in their networks, especially regarding decision-making about network goals and activities that are more significant to their contexts.

Originality/value - This is a national study of a recent school improvement strategy, which provides evidence, from the perspective of school leaders, of its strengths and improvement areas. This study shows that despite being in a competitive context, principals and curriculum coordinators value the opportunities to learn from and with others. These results can be of value for other contexts attempting to promote school networks as a means for school and system improvement.
\end{abstract}

\section{Keywords}

Collaboration, Networked Improvement, School Networks, Professional Capital, School Improvement 


\section{Promoting collaboration in a competitive context: school improvement networks in Chile}

\section{Introduction}

Networking has been advanced as a promising strategy for urban school reform and continuous improvement by promoting collaboration between professionals and organizations (Leithwood and Azah, 2016; Rincón-Gallardo and Fullan, 2016; West, 2010; Wohlstetter et al., 2003). Chile has echoed this international trend, and recent educational reforms have focused on promoting collaboration between schools through a networked approach. However, this implies an important cultural change, since competition is a prominent feature of the Chilean school system due to its market-oriented principles, inspired by Milton Friedman's neoliberal approach to social policy (Friedman, 1962).

The assumption of this neoliberal model, implemented in Chile during Pinochet's dictatorship (1973 - 1990), is that market forces would regulate educational institutions, making them more efficient in response to local and global economic interests (Carnoy and McEwan, 2001). Three key educational policies consistent with this market model have pushed schools towards competition: a) the privatization of public education by transferring the administration of public schools to municipalities and private for-profit and non-profit organizations; b) a voucher system based on student enrollment and attendance, set up to finance the educational system; and, c) the creation of a national standardized test (SIMCE) for high-stakes accountability purposes. These policies, connected, foster a business capital model (Shirley, 2016) where schools from different administrators (municipal and private-subsidized) compete against each other for students' enrolment in order to secure the necessary resources to enable them to subsist, while SIMCE results are expected to inform families' choice of schools for their children (Bellei and Vanni, 2015; Pino-Yancovic, 2015).

After the dictatorship, throughout the 1990s, the goal was to regulate the educational market and support schools and teachers through a series of policies that did not challenge the underlying assumptions of marketization. These policies improved issues such as infrastructure and available resources for municipal and private-subsidized schools, but there were no significant gains in educational outcomes as the system continued to reproduce its structural segregation (Ahumada et al., 2012; Osses et al., 2015; Román and Murillo, 2012). A persistent discontent emerged from students and the civil society in the first decade of the 2000 s, having a 
direct impact on the media and the public agenda for education (Fuentes, 2006; Pedreira Elizalde, 2014: Pitton, 2012). Students' demonstrations in 2006 and 2011, and the ensuing parents' and teachers' movements provided the momentum for proposing and enacting deep reforms to the market model during President Bachelet's second term (2014 - 2017).

In this context, in 2015, the Chilean Ministry of Education (MINEDUC) developed and launched the School Improvement Networks (SINs) strategy. The goal of these networks is for principals and curriculum coordinators to learn collectively as peers, have the opportunity to adapt national policies to their own context, discuss and analyze problems that they face in their own school to jointly decide the best path of action, and share successful experiences. That year, nearly 500 networks across all 15 regions of the country were created to support the improvement of municipal schools and, in some cases, also included private-subsidized schools. These networks currently consist of five to ten schools, represented by their principal and curriculum coordinator, in addition to a Ministry supervisor that usually coordinates the work of the network, and a representative of the municipal administrator. These SINs seek to generate and transfer good educational practices and analyze processes and trajectories of school improvement among school leaders, through collaborative work and collective reflection (MINEDUC, 2016).

Chile has developed several networking initiatives in the past. A well-known program is MECE RURAL, focused on improving rural education by creating networks of Rural Microcenters (Moreno, 2007). Additionally, municipal administrators of education have also formed and supported thematic educational networks to improve Early Childhood Education, English as a Second Language, Spanish Language, and Mathematics (Fuentealba and Galaz, 2008). Other networks have focused on the professional development of teachers, such as the Teachers of Teachers Network (Montecinos et al., 2014). Nevertheless, the SINs strategy is the first networking initiative at the national level.

Despite schools being expected to collaborate with others in networks, the SINs strategy has faced the challenge of being implemented without changing the core elements of the market model of education, such as the high-stakes, individual accountability system (Flórez Petour, 2013; Pino-Yancovic, 2015; Pino-Yancovic, et al., 2016). The Education Quality Agency creates an annual classification scheme where schools are individually categorized with a high, medium, 
med-low, or insufficient performance. These categories are constructed considering different indicators, among which the most relevant is the national standardized test. Schools that are classified as insufficient for four consecutive years can be closed by the Ministry of Education, which makes them face a great deal of pressure to improve. These market-oriented conditions and individual school performance to classify schools of the Chilean educational system could work against schools developing collaborative relationships, based on mutual reciprocity and trust, as schools have to worry about their individual performance.

The study of the implementation of the SINs strategy is relevant because school networks can become privileged spaces to disseminate information and practices among schools and their professionals, creating the opportunity for knowledge-sharing and innovation aimed at improving student achievement (Brown and Flood, 2019). Consequently, it is relevant to develop a national analysis of how SINs have functioned from the perspective of their own participants, and query what has been their effect in terms of overcoming the aforementioned challenges for collaboration.

This paper is structured in four sections. Firstly, a review of relevant literature is presented around key concepts: networking, professional capital and networked improvement. Secondly, the methodology of the study is described, where the instrument employed, application procedure, ethical considerations, and participants are introduced. Third, the descriptive results of the questionnaire are presented, along with sub-group statistical analyzes by school performance categories and by different roles within these schools and networks. Finally, the paper advances a set of conclusions regarding the way SINs have addressed the issue of collaboration in a competitive environment.

\section{Literature review}

\section{Networking}

Networking can be understood as the work between actors from different organizations within a collaborative arrangement. According to Muijs, West and Ainscow (2010), networking consists of "at least two organizations working together for a common purpose" (p. 6); this collaborative work would mean that they perform "joint activities between actors from different organizations within the network" (p. 6). 
The literature highlights essential conditions that help the development of effective school networks. One of the most recurrent recommendations for an effective network is that it should have a clear, meaningful and specific purpose on which partners can collaborate on (Chapman et al., 2016; Leithwood, 2019, Leithwood and Azah, 2016; Muijs et al., 2010; Rincón-Gallardo and Fullan, 2016; Poortman and Brown, 2018). According to Leithwood (2019), network leadership support the development of effective school networks, because implies, among other aspects, helping network members to identify clear goals and purposes.

A second aspect of networking is developing a collective agenda in response to the interests of its members, establishing a sense of shared responsibility for its outcomes. Being part of the network depends on the interest to actively participate in the task that the network has defined, which is related with member's sense of belonging to a collective, despite their differences (Leithwood and Azah, 2016). Most of the conflicts and problems related to networking arise where power and distrust are part of the network reality. A key feature of networking is to agree on ways to solve these problems by establishing communication channels and enabling new leaders to help and mediate these conflicts (Leithwood, 2019).

A third aspect of networking is related to knowledge creation and knowledge mobilization (Brown and Flood, 2019; Reid, 2014). According to Leithwood (2019), networks are particularly well suited to make explicit the tacit, implicit procedural knowledge of their members. The tacit knowledge becomes explicit when conversations about practices are a central topic in the networks. When everyday practices are shared and discussed, then it is possible to search collective solutions to problems that leaders are facing in their own schools (Katz and Earl, 2010). Additionally, the literature advances collaborative inquiry or reflective professional inquiry as a methodology that allows participants to define a collective focus, gather and analyze data, and monitor the activities they conduct (Chapman, et al, 2016; Pino, et al., 2018; Poortman and Brown, 2018). Therefore, it is important to study how networks connect and help participants develop solutions to solve the challenges they face in their own schools.

\section{Professional Capital}

Shirley (2016) advocates for the notion of professional capital as a conceptual framework to think about collaborative arrangements, such as networks of schools. This approach seems appropriate to study the Chilean SINs strategy, as it attempts to challenge the market model of 
education based on competition by adopting a systemic approach to educational improvement based on collaboration. Professional capital integrates three interrelated dimensions: human capital, social capital and decisional capital (Hargreaves and Fullan, 2012).

Human capital reflects individual talent and the requisite knowledge and skills to improve students learning. Human capital of an educational professional includes the "skills, knowledge, empathy, passion, confidence, charisma and leadership" (Chapman et al., 2016, p. 180). Human capital has been considered part of the formal continuing training and learning throughout a teacher's career (Darling-Hammond, 2013).

Social capital involves teachers collaborating with each other and with other professionals within and beyond their schools. Social capital exists in the relationship of individual talents, and it depends on how a group of professionals share their knowledge and skills (Chapman at al., 2016). Muijs and colleagues (2010) argue that networks facilitate the creation of social capital through the flow of information and harnessing of resources from different actors collaborating. The interaction among leaders and teachers required to allow the mobilization of knowledge has a significant impact on teaching practices (Campbell, 2017; Reid, 2014). Social capital requires teamwork and a culture of collaboration that is reflected in a learning-oriented network, and a sense of trust that fosters good and effective communication (Hargreaves and Fullan, 2012; Rincón-Gallardo and Fullan, 2016).

Decisional capital involves opportunities for teachers to exercise informed professional judgment, to have agency and responsibility, and to be trusted as practitioners in their own profession (Campbell, 2017; Chapman et al., 2016). Teachers need to make decisions considering the context and features of each of their diverse students. There is a significant difference between applying a good technique and being a good professional.

School networks are a privileged place to integrate human, social and decisional capital with the goal of fostering educational improvement. When participants share experiences, ideas, and practices based on effective collaboration processes (social capital), they will also have the chance to make decisions together (decisional capital), thus, the network can be an opportunity to develop their own professional knowledge (human capital). 


\section{Networked improvement}

Research on school networks reflects how useful they have been to improve student achievement, especially in challenging contexts (Chapman and Muijs, 2014). There is also evidence that district-wide practices related to the developing of school networks have significant positive effects on focused instruction, which in turn has a significant positive effect on student achievement (Lee et al., 2012). Networks have helped to create a path for the professional development of principals (Chapman et al., 2015; Chapman et al., 2016; PinoYancovic et al., 2017), reduce the gap between schools at different levels of achievement (Ainscow et al., 2016; Katz and Earl, 2010), develop and support bottom-up policies with a focus on health and equality (Azorín and Muijs, 2018), and promote the systemic improvement of education (González et al., 2017; Leithwood and Azah, 2016; Muijs, West and Ainscow, 2010; Rincón-Gallardo and Fullan, 2016).

To study network outcomes, Leithwood (2019) presents a three-level model. The author identifies individual-level outcomes, which include professional capacities for school improvement and the provision of instructional support to teachers; individual affective or emotional outcomes, such as job satisfaction, organizational commitment, and professional selfefficacy; and collective outcomes, including "improvements in the flow of ideas across school leaders in the district and among school and district leaders (...) school leaders' increased levels of cooperation and willingness to work together, as well as increased search for innovative ideas and practices on the part of school and district leaders" (p. 7).

Individual-level cognitive and affective outcomes are particularly relevant for the SINs strategy since they aim to facilitate principals' and curriculum coordinators' use of network knowledge to solve challenging issues in their own schools.

Although school networks have shown diverse benefits for individuals, schools and communities, they are far from being a panacea. In fact, researchers have highlighted that ineffective school networks can harm the educational system (Rincón-Gallardo and Fullan, 2016) and that there is a dark side to collaboration (Chapman, 2015), in which professionals waste valuable time because they do not genuinely engage with their partners or try to take advantage of others. The literature also highlights that networks can develop inter-organizational fragmentation and struggles between members, causing them to lose sight of the public 
objectives that the network should be serving (Mayne and Rieper, 2003). Similarly, when network relations are too tight and centralized they can develop groupthink, meaning that they can become self-protective about mainstream ideas and solutions to problems, be unwilling to change, and discourage innovative practices (Ehren and Perryman, 2018). Networks can also incite resistance from their participants, especially when they function in a hierarchized manner and relationships are centralized around few people. Instead of promoting collaborative learning based on horizontality, centralized networks could, for instance, force actors to apply and replicate specific strategies (Greany and Ehren, 2016).

Given these caveats related to the implementation of school networks, it is relevant to analyze the functioning and impact of the SINs strategy from the perspective of principals and curriculum coordinators that participate in these networks across the country. Examining how these actors perceive the functioning of their SINs, would allow exploring if and how this strategy has been effective in promoting a collaborative approach to educational improvement in the Chilean system. For that reason, in this paper, networking, professional capital and networked improvement are studied at a national level. Networking is appraised in terms of how participants perceive the network organization and support of collective work. Professional capital is gauged according to how participants perceive their own professional development in the networks, in terms of social capital and decisional capital. Finally, networked improvement is assessed based on how participants perceive the effects of the networks in the improvement of their schools.

\section{Methodology}

\section{Instrument}

To analyze the SINs strategy nation-wide, quantitative and qualitative data were collected employing an adaptation of the Educational Collaborative Network Questionnaire (ECN-Q) developed by Díaz-Gibson and colleagues $(2014)^{1}$. The original instrument was organized into two parts: a section with 16 Likert-scale items focused on the respondents' level of agreement (ranging from strongly disagree to strongly agree); and a section with 15 multiple-choice items.

\footnotetext{
${ }^{1}$ In this paper we present an analysis of the quantitative data.
} 
This instrument was first adapted and then validated in 2016 through a series of steps. First, the questionnaire items were translated from English into Spanish and all of them were transformed into Likert-scale items. The original instrument is composed of two dimensions: Social Capital and Network Organization, as a way of measuring how networks of schools and other social organizations arrange their collaboration. Considering both the current literature on school networks (Chapman et al., 2016; Leithwood, 2019; Rincón-Gallardo and Fullan, 2016), and the Chilean context, which national aim is to promote collaboration among schools to improve their practices and students' achievement (MINEDUC, 2016), the instrument was adapted to reflect the conditions of SINs.

Second, the translated items were analyzed by six expert judges in education, who had experience in research or projects about school networks. This analysis considered content relevance and clarity. Once the instrument was adjusted according to the criteria of the expert judges, it was sent for review to a group of Ministry professionals, responsible for the coordination of the SINs strategy. Finally, during the second semester of 2016, a pilot application of the adapted questionnaire was carried out with principals and curriculum coordinators participating in ten $\mathrm{SINs}^{2}$ of two regions of the country. The pilot application was mainly performed to analyze the quality and clarity of each item. The participants of this piloting considered that the questionnaire items were clear and relevant, and only some minor grammatical and content adjustments were suggested and introduced for the final version.

As a result of these steps, the adapted version of the ECN-Q consists of 32 Likert-scale items and five open-ended questions inviting principals and curriculum coordinators to express their views on (i) aspects that facilitate networking; (ii) aspects that hinder networking; (iii) the support received from the network; (iv) the support given to the network; and (v) advice to improve networking. This final version adequately reflects the previously described characteristics and aims of the SINs, which have a preferential focus on improving the school leaders' practice, impacting the teaching and learning conditions in schools ${ }^{3}$.

\footnotetext{
2 The piloting of the questionnaire was responded by 32 school leaders (20 principals and 12 curriculum coordinators) from ten school networks.

${ }^{3}$ Following the experts and Ministry professionals' revision, the adaptation of the questionnaire includes one more item than the original instrument. This change aimed for the questionnaire to be better aligned with both the Chilean context and the objective of the school improvement networks (SINs) strategy to support the work of school leaders.
} 


\section{Application procedure}

To identify the principals and curriculum coordinators who would participate in the study, a database of the schools participating in SINs for the year 2017 was requested to Chilean Ministry of Education. This database was revised, corrected and updated by adding contact information (email and phone number) using public data for each school participating in networks, and subsequently calling schools to check the names of principals and curriculum coordinators participating in SINs.

The questionnaire was applied between July and October of 2017 through an online platform. The link to the online questionnaire was sent to the email addresses of all principals and curriculum coordinators correctly identified in the database. Additionally, during the application process, these participants were contacted directly by telephone to confirm they had received the email with the link to the questionnaire and encourage them to answer it.

The use of a self-reported questionnaire required to address a potential response bias by explicitly asking the participants for their perceptions of both positive and negative aspects of the SINs strategy, and by reassuring that all responses would be treated anonymously. However, there may be an issue of self-selection in these responses, as schools where participants who did not answer the questionnaire could be, in some respects, different from schools of those who did answer it. The partial representation of the sample with respect to all schools in the SINs strategy is a limitation of the study, and therefore its results need to be taken with some caution.

\section{Ethical considerations}

Informed consent was sought from participants via a cover letter about the study that accompanied the email invitation to answer the questionnaire. This letter explained the aims of the study, ensuring people about confidentiality and anonymity in reporting the data collected through this instrument. It detailed the expected and potential use of the information, specifying that it would only be used for academic and research purposes. The letter also expressed the possibility of declining to participate in the study or withdrawing from it at any point and provided contact details of the coordinator of the project in case participants required additional information. 


\section{Participants}

The link to the online questionnaire was sent to 3,096 principals and curriculum coordinators who were in the Ministry's database. A total of 1,789 people answered the questionnaire. The majority of participants identified as female (63\%). Table 1 shows that, from all valid answers, just over half of the participants are principals (54\%) and a significant proportion of them are curriculum coordinators (40\%). Only a small group indicates occupying another role (6\%). Moreover, respondents to the questionnaire participate in 398 out of the 483 networks in operation during 2017 , representing $82 \%$ of the total number of SINs at the national level ${ }^{4}$.

\section{[Table 1. Distribution of participants by position]}

\section{Factor analysis}

Due to the changes made to the original instrument, an exploratory factor analysis was conducted to assess the relevance of the new questionnaire to measure the latent dimensions for network functioning. The Kaiser-Meyer-Olkin test confirms the adequacy of these survey data for such analysis $(\mathrm{KMO}=0.986)$, which was conducted using Stata 14.

Table 2 shows the loadings by factors and items using promax rotation, thus, assuming that the three factors are correlated. The correlation matrix of the promax rotated common factors confirms that this is the case, showing correlations between factors of 0.671-0.688. Using a minimum loading threshold of 0.40 , results indicate an adequate simple structure of the questionnaire measuring three dimensions: networking, professional capital, and networked improvement ${ }^{5}$. Additionally, the uniqueness indicators for each item range from 0.15 to 0.42 , thus showing that all items in the questionnaire would be sufficiently explained by these common factors. These results would be in line with the conceptual framework developed for analyzing Chilean school networks.

\section{[Table 2. Rotated factor loadings, by items and dimensions]}

\footnotetext{
${ }^{4}$ This study focuses on assessing how the SINs strategy is perceived at the national level, as the reduced variability of the data at the network level hinders the statistical analysis at other levels (e.g. multilevel regression analysis).

5 There is one exception where an item (I31) shows a slightly lower loading. Additionally, in the few cases where similar loadings are shown in more than one factor (four items out of 32), their classification was prioritized based on the reviewed literature.
} 


\section{Findings}

This section includes the data analysis about SINs functioning in Chile. It considers a description of the factors or dimensions of network functioning measured in the questionnaire, followed by sub-group statistical analyzes. The school-level analysis is based on the performance categories developed by the Chilean Education Quality Agency. At the participant level, subgroup analyses are conducted by different actors within schools (principals and curriculum coordinators), by principals from different school contexts (urban and rural), and by the role these actors take within the school network (coordinators and general members).

\section{Descriptive analysis}

The sample analyzed compiles $1,723^{6}$ questionnaires representing 1,375 schools participating in networks. The majority of the schools in the sample (78\%) have one valid questionnaire completed, while the rest have two or three questionnaires validly responded. Additionally, $96 \%$ of the respondents have valid answers for at least 30 of the 32 Likert-scale items included in the instrument, showing a good response pattern.

Table 3 shows the descriptive statistics for the dimensions measured. Professional capital is the highest rated scale (mean=5.10), followed closely by networked improvement (mean=4.88) and networking (mean=4.80). The three scales included in the questionnaire also show a high internal consistency, with Cronbach's alphas between 0.94 and 0.97.

\section{[Table 3. Summary statistics for school network scales]}

In the networking dimension, between $55 \%$ and $80 \%$ of respondents agree or strongly agree with its statements. The highest-rated items are sharing school practices to achieve the network objectives (I26, mean=5.04), developing a shared vision of the network (I21, mean=4.99), and having shared responsibilities among its members (I22, mean=4.91); between $75 \%$ and $80 \%$ of principals and curriculum coordinators strongly agree or agree with these statements. These are positive results, as evidence shows that a feature of an effective school network is that its participants share a common purpose and a sense of shared responsibility to

\footnotetext{
${ }^{6}$ Of the 1,789 answers received, 66 questionnaires were dropped because of missing school ID ( $\mathrm{n}=13$ ), no valid answers $(\mathrm{n}=10)$, and for schools with four or more questionnaires $(\mathrm{n}=43)$.
} 
achieve these goals (Leithwood, 2019; Leithwood and Azah, 2016; Rincón-Gallardo and Fullan, 2016).

However, $12 \%$ of respondents strongly disagree or disagree that the network has established communication channels to connect with community actors and institutions (I19, mean=4.39). In fact, of all items in the questionnaire, this statement shows the lowest level of agreement among curriculum coordinators and principals. Given that the SINs strategy has been implemented since 2015, it is possible that the networks' main challenge has been to develop synergy among its participants. Therefore, it would be understandable that participants could disagree with this item. In addition, the main focus of these networks is school improvement, which differs from other networks with a more community-level focus, such as the experience in Spain (Díaz and Civís, 2011) and Scotland (Chapman et al., 2016).

The professional capital dimension is the most valued by principals and curriculum coordinators; between $73 \%$ and $88 \%$ of respondents agree or strongly agree with its statements. The highest-rated items indicate that all opinions are equally respected, a sense of horizontal membership and freedom of expression, as well as the exchanging of experiences and resources between participant schools (I09, mean=5.29; I13, mean=5.20; I12, mean=5.19; and I31, mean $=5.18$, respectively). This suggests that participants consider that they are sharing their knowledge, which is a significant aspect for the developing of stronger and meaningful networks.

Conversely, the feeling of taking part in the network's decision-making processes (I17, mean $=4.89$ ) shows the lowest rating within this dimension. This result could be problematic, as a significant value of networks is the active participation of its members, which implies the development of decisional capital (Chapman et al, 2016). If networks become comfortable but not challenging places, they can reproduce beliefs instead of promoting change that would lead to improvement (Katz and Earl, 2010).

For the networked improvement dimension, between $64 \%$ and $84 \%$ of respondents agree or strongly agree with its statements. The items with the highest level of agreement are related to the relevance of the network for their own school context (I10, mean=5.18), the use of the network's knowledge in their own school work (I14, mean=5.08), and the commitment towards the work they do in their school improvement network (I02, mean=5.07). Considering 
Leithwood's (2019) analysis of effective leadership networks, these results reflect participants' individual-level cognitive outcomes. Armstrong and Ainscow (2018) highlight that schools that participate in networks within competitive environments require recognizing benefits for their own schools to sustain collaboration. Considering the Chilean context, the results in this dimension are auspicious for the sustainability of the SINs strategy. Yet, 9\% of the respondents disagree or strongly disagree that network activities have improved their leadership skills (I06, mean=4.64). It seems the SINs strategy is yet to promote affective or emotional outcomes contributing to professional self-efficacy (Leithwood and Jantzi, 2008).

Table 4 details the mean and standard deviation for each of the items, as well as the sum of the percentages in the agreement and disagreement ends of the Likert scale. Results show that, on average, curriculum coordinators and principals tend to mainly "agree" with the statements about networking, professional capital and networked improvement.

[Table 4. Summary statistics by item]

\section{School-level analysis}

Considering the annual classification of schools' performance made by the Chilean Education Quality Agency, linear regression models were conducted to compare the mean rates for each dimension between schools classified with high performance and schools with insufficient performance, while also accounting for the school context (urban or rural), and region where it is located.

Table 5 shows that after controlling for these school-level characteristics, highperforming primary schools show a more positive perception of two dimensions: networking and professional capital. However, these differences are not statistically significant at conventional levels. At the same time, results suggest that secondary schools categorized with an insufficient performance value more all three dimensions of network functioning, compared to schools with high performance; however, this is only statistically significant for the networked improvement dimension. Secondary schools face diverse and significant challenges, and receive less financial and technical support from the government (MINEDUC, 2017); therefore, it seems that secondary schools take special advantage of this strategy. Similar evidence is provided by Armstrong and Ainscow (2018), who found that schools in challenging circumstances value 
collaboration with others, especially for professional development opportunities. Our findings support the idea that schools classified as insufficient should not be excluded from school networks. As highlighted by Chapman and Muijs (2014), schools in challenging circumstances can improve their performance by participating in school networks, but the structure and support of these networks require careful consideration of the participants' goals, capabilities and interests.

[Table 5. Subgroup analysis for each dimension, by school performance categories]

\section{Analysis by roles}

The final section of analysis consists of identifying differences in the perception of the dimensions by school and network roles. Following the Chilean educational context, the three network functioning dimensions were compared by different actors within schools (principals and curriculum coordinators), by principals from different school contexts (urban and rural), and by the roles these actors take within their networks (coordinators and general members). In order to do this, linear regression models were used incorporating relevant control variables at the participant and school level, such as gender, years participating in the network, regular attendance to the network meetings, involvement in the network's annual plan, years of experience in the school educational system, and the school type and region where is located.

As shown in Table 6, compared to curriculum coordinators within the same schools, principals have a higher perception of the three dimensions of network functioning, although these are not statistically significant at conventional levels. It is possible that SINs focus on management topics and less on curriculum and teachers' practices, making the SINs strategy less attractive to curriculum coordinators. Principals of rural schools show higher rates than urban school principals in two dimensions: networking and networked improvement; nevertheless, these differences are statistically indistinguishable.

Finally, network coordinators, those who take some responsibility for the administrative aspects of the school networks, evaluate better each dimension compared to regular network members, which is particularly noteworthy in the networked improvement dimension. This may be related to a positive perception of their own work.

[Table 6. Subgroup analysis for each dimension, by school and network roles] 


\section{Discussion}

This study of the SINs strategy shows that despite the competitive environment of the Chilean education system, influenced by high-stake testing and an individual school accountability system, principals and curriculum coordinators seem to have been able to develop common purposes, goals and collective activities for their networks. Notwithstanding previous networking experiences in Chile, this is the first national study that allows describing how school networks are perceived and their significant value for educational improvement, according to principals and curriculum coordinators.

The rationale of improvement of the Education Quality Agency, based on an annual performance classification scheme, follows the logic of individual performance and performativity (Ball, 2010). Conversely, the SINs rationale promotes the idea of systemic improvement instead of supporting schools one by one in an isolated manner. The logic of individual performativity is very well suited for societies with low social cohesion and low group regulation, which should rely on individual survival and self-regulation to achieve internalized outcomes (McCarthy, 2011). Networks rely upon a socially regulated and cohesive society where there is co-responsibility about practices and outcomes, which can be identified as egalitarian groups or societies (Reynolds et al., 2016). What seems to be happening with the SINs strategy is that school leaders are caught in a bureaucracy with a high social regulation but not necessarily with high social cohesion. This might be why some school leaders perceive that school networks provide opportunities for them to share knowledge and practices, but at the same time, that they are not influencing or deciding over the agenda of the network, perhaps the agenda of some networks is defined by the Ministry supervisors.

Another significant finding from this study is how SINs seem especially meaningful to participants from secondary schools categorized as insufficient. Despite the challenges that these schools face, their school leaders seem to be the ones who benefit more from their peers. Therefore, rather than isolating these schools, networks could develop specific mechanisms to support their participation. These schools, compared to schools with high performance, valued more the networked improvement dimension. This dimension is focused on items that link the usefulness of the network to solve practical problems that school leaders face in their schools, while the other dimensions (networking and professional capital) are more related to their professional capacities and professional relationships. School leaders facing challenging 
circumstances may be focused on gaining access to practical strategies from their networks that they can later replicate in their schools. However, the accountability pressure on those schools might lead them to value short-term, mechanistic practices shared in their networks, which might allow them to solve specific problems that they face in their schools, but can only ensure tactical improvement (Chapman, 2004).

Conversely, the SINs strategy is supported by the value of systemic improvement, which echoes the notion of organic improvement. This approach, discussed by Harris (2000), emphasizes the idea that schools improve from a multi-level perspective, where "there is no universally correct starting-point for any school. In each school, context, history, leadership, staffing, incentives, and personal history will vary." (p. 6). An important challenge is how SINs can recognize the diverse needs of their members to foster different paths for improvement by advancing their members' capacities instead of sharing good practices and expecting quick replications.

\section{Limitations and Future Research}

Future studies could look at networks that include schools with different performance levels. This would provide further evidence on their internal dynamics, the specific challenges they face, and how they could be better supported. Also, despite the value of this national survey, more in-depth case studies would be useful to better understand the collaborative practices and knowledge that networks are creating and sharing, which is very relevant to foresee their potential sustainability ${ }^{7}$. Social network analysis of the SINs would also be valuable to explore if this national strategy is creating a new culture of collaboration, where participants are able to build trustful professional relationships. Finally, additional statistical analyses on the effect of specific SINs on student learning, providing a clear account of their characteristics, collaborative practices and knowledge, would highlight how networks could become a suitable path for sustainable and systemic educational improvement.

\section{Conclusion}

The results of this national study pose significant opportunities and challenges for school networks that operate in competitive contexts. First, data from the questionnaire indicate that an

\footnotetext{
${ }^{7}$ A book will soon be released (Pino-Yancovic, et al., in press), which looks at this strategy, its implementation and sustainability, using data from a national survey and case studies from different school contexts of the country.
} 
important percentage of participants perceive that their ideas are not being taken into consideration for the agenda of the network, and some participants do not feel included in the decision-making processes of their networks. This would suggest a need for more autonomy for participants to define topics for their networks, which would help sustain their participation and commitment in order to support the development of decisional capital within networks. Second, the sustainability and impact of school networks are related to their ability to affect their local context, meaning a clear alignment with their communities' needs and challenges. To increase their effectiveness, these networks could evolve to have a more meaningful articulation with local authorities and social services.

Although findings show that participants of SINs perceive their networks as valuable spaces to solve problems in their schools, it seems that networks do not effectively articulate with other community organizations. Recent literature on school networks advances the importance of promoting educational networks beyond schools, developing partnerships between schools and other public services to tackle complex socio-educative issues (Chapman et al., 2016). The findings of this national study reflect that the development of school networks should be aligned with a systemic perspective about school improvement. Then, networks could take advantage of partnering with social and care organizations to address the challenges that students face considering underlying socio-economic factors.

In summary, this study helps to understand the value of school networks and their challenges to promote collaboration in a competitive context from a national perspective. Findings from this study support the idea of developing policies that promote collaboration and allow school leaders to share their knowledge and experiences for systemic improvement, instead of concentrating on individual accountability mechanisms. Educational policies that follow this path could have a deeper impact not only on the professional capital of school leaders, but also on improving the quality and equity of the education system as a whole.

\section{References}

Ahumada, L., Montecinos, C. and González, A. (2012), “Quality Assurance in Chile’s Municipal Schools: Facing the Challenge of Assuring and Improving Quality in Low Performing Schools", edited by Savsar, M.Quality Assurance and Management, InTechOpen, pp. 183192. 
Ainscow, M., Dyson, A., Goldrick, S. and West, M. (2016), "Using collaborative inquiry to foster equity within school systems: opportunities and barriers ${ }^{1 "}$, School Effectiveness and School Improvement, Vol. 27 No. 1, pp. 7-23.

Armstrong, P.W. and Ainscow, M. (2018), "School-to-school support within a competitive education system: views from the inside", School Effectiveness and School Improvement, Vol. 29 No. 4, pp. 614-633.

Azorín, C. and Muijs, D. (2018), "Redes de colaboración en educación. Evidencias recogidas en escuelas de Southampton", Profesorado, Revista de Currículum Y Formación Del Profesorado, Vol. 22 No. 2, pp. 7-27.

Ball, S.J. (2003), "The teacher's soul and the terrors of performativity", Journal of Education Policy, Vol. 18 No. 2, pp. 215-228.

Bellei, C. and Vanni, X. (2015), "Chile: The Evolution of Educational Policy, 1980-2014", in Schwartzman, S. (Ed.), Education in South America, Bloomsbury Academic.

Brown, C. and Flood, J. (2019), Formalise, Prioritise and Mobilise: How School Leaders Secure the Benefits of Professional Learning Networks, Emerald Group PUBL.

Campbell, C. (2017), "Realizing professional capital by, for, and with the learning profession: lessons from Canada", in Malone, H.J., Rincón-Gallardo, S. and Kew, K. (Eds.), Future Directions of Educational Change Social Justice, Professional Capital, and Systems Change, Routledge, New York, pp. 117-134.

Carnoy, M. and McEwan, P. (2001), "Privatization Through Vouchers in Developing Countries: The Cases of Chile and Colombia", Privatizing Education: Can The School Marketplace Deliver Freedom Of Choice, Efficiency, Equity, And Social Cohesion?, Routledge, New York, pp. 151-177.

Chapman, C. (2015), "From one school to many: Reflections on the impact and nature of school federations and chains in England", Educational Management Administration \& Leadership, Vol. 43 No. 1, pp. 46-60.

Chapman, C. (2004), "Leadership for Improvement in Urban and Challenging Contexts", London Review of Education, Vol. 2 No 2, pp 95-108

Chapman, C., Chestnutt, H., Friel, N., Hall, S. and Lowden, K. (2016), "Professional capital and collaborative inquiry networks for educational equity and improvement?", Journal of Professional Capital and Community, Vol. 1 No. 3, pp. 178-197.

Chapman, C., Lowden, K., Chestnutt, H.R., Hall, S., McKinney, S., Hulme, M. and Friel, N. (2015). The School Improvement Partnership Programme: Using Collaboration and Inquiry to Tackle Educational Inequity, Education Scotland, p. 89.

Chapman, C. and Muijs, D. (2014), "Does school-to-school collaboration promote school improvement? A study of the impact of school federations on student outcomes", School Effectiveness and School Improvement, Vol. 25 No. 3, pp. 351-393.

Darling-Hammond, L. (2013), Powerful Teacher Education: Lessons from Exemplary Programs, 1st ed., Jossey-Bass, San Francisco, CA.

Díaz-Gibson, J., Civís-Zaragoza, M. and Guàrdia-Olmos, J. (2014), "Strengthening education through collaborative networks: leading the cultural change", School Leadership \& Management, Vol. 34 No. 2, pp. 179-200.

Díaz, J. and Civís, M. (2011), "Redes Socioeducativas promotoras de capital social en la comunidad: un marco teórico de referencia", Cultura y Educación, Vol. 23 No. 3, pp. 415429. 
Ehren, M. and Perryman, J. (2018), "Accountability of school networks: Who is accountable to whom and for what?", Educational Management Administration \& Leadership, Vol. 46 No. 6, pp. 942-959.

Flórez Petour, M.T. (2013), Análisis Crítico de La Validez Del Sistema de Medición de La Calidad de La Educación (Simce), Oxford University Centre for Educational Assessment, p. 123.

Friedman, M. (1962), Capitalism and Freedom, University of Chicago Press, Chicago.

Fuentealba, R. and Galaz, A. (2008), "La reflexión como recurso para la mejora de las prácticas docentes en servicio: el caso de las redes pedagógicas locales en Chile", in Cornejo, J. and Fuentealba, R. (Eds.), Prácticas Reflexivas Para La Formación Profesional Docente: ¿Qué Las Hace Eficaces?, Ediciones Universidad Católica Silva Henríquez, Santiago, Chile, pp. 141-167.

Fuentes, C. (2006), "Juventud y participación política en el Chile actual", Revista Observatorio de Juventud. Instituto Nacional de La Juventud, Vol. 3 No. 11, pp. 51-55.

González, A., Pino-Yancovic, M. and Ahumada-Figueroa, L. (2017), "Transitar desde el mejoramiento escolar al mejoramiento sistémico: Oportunidades y desafíos de las redes escolares en Chile", Lideres Educativos, Centro de Liderazgo Para El Mejoramiento Escolar: Chile, Vol. Nota Técnica N², available at: https://www.lidereseducativos.cl/wpcontent/uploads/2017/07/NT-2-2017.pdf.

Greany, T. and Ehren, M. (2016), "Written evidence to Education Select Committee inquiry into the performance, accountability and governance of Multi-Academy Trusts", available at: http://data.parliament.uk/writtenevidence/committeeevidence.svc/evidencedocument/educa tion-committee/multiacademy-trusts/written/32050.html.

Hargreaves, A. and Fullan, M. (2012), Professional Capital: Transforming Teaching in Every School, Routledge, London.

Harris, A. (2000). "What works in school improvement? Lessons from the field and future directions", Educational Research, Vol. 42. No. 1, pp 1-11.

Katz, S. and Earl, L. (2010), "Learning about networked learning communities", School Effectiveness and School Improvement, Vol. 21 No. 1, pp. 27-51.

Lee, M., Seashore Louis, K. and Anderson, S. (2012), "Local education authorities and student learning: the effects of policies and practices", School Effectiveness and School Improvement, Vol. 23 No. 2, pp. 133-158.

Leithwood, K. (2019), "Characteristics of effective leadership networks: a replication and extension", School Leadership \& Management, Vol. 39 No. 2, pp. 175-197.

Leithwood, K. and Azah, V.N. (2016), "Characteristics of effective leadership networks", Journal of Educational Administration, Vol. 54 No. 4, pp. 409-433.

Leithwood, K. and Jantzi, D. (2008), "Linking Leadership to Student Learning: The Contributions of Leader Efficacy", Educational Administration Quarterly, Vol. 44 No. 4, pp. 496-528.

Mayne, J., and Rieper, O. (2003), "Collaborating for public service quality: the implications for evaluation", in A. Gray, B. Jenkins, F. Leeuw, \& J. Mayne (Eds.), Collaboration in public services: The challenge for evaluation, New Brunswick: Transaction Publishers, pp. 105131.

McCarthy, C. (2011). Afterword: The unmaking of education in the age of globalization, neoliberalism and information. In M. Peters and E. Bulut (Eds.), Cognitive capitalism, education and digital labor. Peter Lang Publishing, New York, NY. 
MINEDUC. (2016), "Orientaciones para el apoyo técnico-pedagógico al sistema escolar", División de Educación General, available at: https://bibliotecadigital.mineduc.cl/handle/20.500.12365/2017.

MINEDUC. (2017), “¿Hacia dónde avanza el sistema educativo en Chile? Análisis de las recomendaciones OCDE contenidas en Evaluaciones de Políticas Nacionales de Educación: Educación en Chile (2004-2016) en el contexto de la Reforma en marcha", Serie Evidencias, Vol. 37, p. 36.

Montecinos, C., Pino, M., Campos-Martinez, J., Domínguez, R. and Carreño, C. (2014), "Master teachers as professional developers: Managing conflicting versions of professionalism", Educational Management Administration \& Leadership, Vol. 42 No. 2, pp. 275-292.

Moreno, C. (2007), "Las escuelas rurales en Chile: la municipalización y sus fortalezas y debilidades", Revista Digital ERural, Educación, Cultura y Desarrollo Rural, Vol. 4 No. 8.

Muijs, D., West, M. and Ainscow, M. (2010), "Why network? Theoretical perspectives on networking", School Effectiveness and School Improvement, Vol. 21 No. 1, pp. 5-26.

Osses, A., Bellei, C. and Valenzuela, J.P. (2015), "External technical support for school improvement: critical issues from the Chilean experience", Journal of Educational Administration and History, Vol. 47 No. 3, pp. 272-293.

Pedreira Elizalde, P. (2014), El Movimiento Estudiantil Chileno: Análisis de Las Demandas de Los Estudiantes y Del Impacto Político de Las Movilizaciones, Tesis de Grado, Universitat Autònoma de Barcelona, Facultat de Ciències Polítiques i de Sociologia, available at: https://ddd.uab.cat/record/119181.

Pino-Yancovic, M., González, A., Ahumada, L. and Chapman, C. (IN PRESS). School Improvement Networks and Collaborative Inquiry: Fostering Systemic Change in Challenging Contexts. Emerald, Bingley, UK.

Pino-Yancovic, M., González, A. and Ahumada, L. (2018), "Indagación colaborativa: Elementos teóricos y prácticos para su uso en redes educativas", Lideres Educativos, Centro de Liderazgo Para El Mejoramiento Escolar: Chile, Vol. Informe Técnico №4, available at: https://www.lidereseducativos.cl/wp-content/uploads/2019/02/IT4_INDAGACIONCOLABORATIVA-ELEMENTOS-TEORICOS-Y-PRACTICOS-PARA-USO-ENREDES 27-11-18.pdf.

Pino-Yancovic, M. (2015), "Parents' defense of their children's right to education: Resistance experiences against public school closings in Chile", Education, Citizenship and Social Justice, Vol. 10 No. 3, pp. 254-265.

Pino-Yancovic, M., González, A., Ahumada, L. and Del Pozo, M.F. (2017), "Seguimiento a egresados del Diplomado en Liderazgo Sistémico y Aprendizaje en Red: ¿Qué consideran valioso y útil a un año de finalizada la formación?", Lideres Educativos, Centro de Liderazgo Para El Mejoramiento Escolar: Chile, Vol. Nota Técnica N ${ }^{\circ}$, available at: https://www.lidereseducativos.cl/wp-content/uploads/2017/12/NT8 MP_L2.pdf.

Pino-Yancovic, M., Oyarzún Vargas, G. and Salinas Barrios, I. (2016), "Crítica a la rendición de cuentas: Narrativa de resistencia al sistema de evaluación en Chile", Cadernos CEDES, Vol. 36 No. 100, pp. 337-354.

Pitton, V. (2012), Neoliberalization of Educational Policy Discourses in Chile, PhD Dissertation, University of Illinois at Urbana-Champaign, Department of Philosophy in Educational Policy Studies, available at: http://hdl.handle.net/2142/32033. 
Poortman, C. and Brown, C. (2018), "The importance of professional learning networks", in Brown, C. and Poortman, C. (Eds.), Networks for Learning: Effective Collaboration for Teacher, School and System Improvement, 1st Edition., Routledge, London, pp. 10-19.

Reid, S. (2014), "Knowledge influencers: leaders influencing knowledge creation and mobilization", Journal of Educational Administration, Vol. 52 No. 3, pp. 332-357.=

Reynolds. D., Chapman. C., Clarke, P., Muijs, D., Sammons, P. and Teddlie, C. (2016). Conclusion: The future of educational effectiveness and improvement research, and some suggestions and speculations. In Chapman, C., D. Muijs, D.Reynolds, P. Sammons, and C. Teddlie (Eds.) The Routledge international handbook of educational effectiveness and improvement: Research, policy, and practice. Routledge, New York, NY.

Rincón-Gallardo, S. and Fullan, M. (2016), "Essential features of effective networks in education", Journal of Professional Capital and Community, Vol. 1 No. 1, pp. 5-22.

Román, M. and Murillo, F.J. (2012), "Políticas educativas de apoyo a escuelas de sectores pobres y de bajo logro académico en Chile: 1990-2011”, Revista de Educación, pp. 46-66.

Shirley, D. (2016), "Three forms of professional capital: systemic, social movement, and activist", Journal of Professional Capital and Community, Vol. 1 No. 4, pp. 302-320.

West, M. (2010), "School-to-school cooperation as a strategy for improving student outcomes in challenging contexts", School Effectiveness and School Improvement, Vol. 21 No. 1, pp. 93-112.

Wohlstetter, P., Malloy, C.L., Chau, D. and Polhemus, J.L. (2003), "Improving Schools through Networks: A New Approach to Urban School Reform”, Educational Policy, Vol. 17 No. 4, pp. 399-430. 
Table 1. Distribution of participants by position

\begin{tabular}{lll}
\hline Current position & Obs & Percentage \\
\hline Principal & 956 & $54 \%$ \\
Curriculum coordinator & 722 & $40 \%$ \\
Other & 108 & $6 \%$ \\
\hline Total & 1,786 & $100 \%$
\end{tabular}

Note: Three participants did not provide their position details. 
Table 2. Rotated factor loadings, by items and dimensions

\begin{tabular}{|c|c|c|c|c|}
\hline & Networking & $\begin{array}{c}\text { Professional } \\
\text { Capital }\end{array}$ & $\begin{array}{l}\text { Networked } \\
\text { Improvement }\end{array}$ & Uniqueness \\
\hline In my network we evaluate how our work contributes to our schools' improvement (I27) & 0.66 & 0.03 & 0.24 & 0.23 \\
\hline $\begin{array}{l}\text { In my network there are norms for dealing with conflict that arise as a result of differences in } \\
\text { opinions (I24) }\end{array}$ & 0.65 & 0.21 & 0.03 & 0.28 \\
\hline My network contributes to solve problems at our own schools (I28) & 0.60 & -0.01 & 0.39 & 0.17 \\
\hline In my network we have created new knowledge by searching for solutions to shared issues (I30) & 0.60 & 0.00 & 0.38 & 0.15 \\
\hline $\begin{array}{l}\text { My network established mechanisms and communications channels to link up with community } \\
\text { actors and institutions (I19) }\end{array}$ & 0.59 & -0.03 & 0.23 & 0.42 \\
\hline In my network, we have shared responsibilities among its members (I22) & 0.58 & 0.32 & 0.04 & 0.22 \\
\hline $\begin{array}{l}\text { In my network there are leaders who help resolve differences in opinion and internal conflicts } \\
\text { (I25) }\end{array}$ & 0.56 & 0.23 & 0.08 & 0.30 \\
\hline $\begin{array}{l}\text { My network facilitates the development of skills and professional development of its members } \\
\text { (I29) }\end{array}$ & 0.55 & 0.08 & 0.34 & 0.18 \\
\hline $\begin{array}{l}\text { My network's agenda is developed based on the priorities and interests expressed by its } \\
\text { participants (I23) }\end{array}$ & 0.54 & 0.26 & 0.10 & 0.27 \\
\hline $\begin{array}{l}\text { The members of my network share their schools' practice to achieve our network objectives } \\
\text { (I26) }\end{array}$ & 0.52 & 0.30 & 0.12 & 0.21 \\
\hline Being in the network fosters a shared view for defining our network needs (I21) & 0.50 & 0.25 & 0.21 & 0.22 \\
\hline My interest to participate in network meetings has increased since the first meeting (I32) & 0.48 & 0.04 & 0.43 & 0.23 \\
\hline The members of my network participate actively in the planned activities (I18) & 0.45 & 0.28 & 0.18 & 0.29 \\
\hline In my network, I feel I participate at the same level as other members (I13) & 0.07 & 0.73 & 0.11 & 0.23 \\
\hline $\begin{array}{l}\text { In my network, the opinions of principals and curriculum coordinators are equally respected } \\
\text { than those of general members (I09) }\end{array}$ & 0.06 & 0.72 & 0.06 & 0.33 \\
\hline In my network I feel there is trust to freely express my perceptions and disagreements (I12) & 0.17 & 0.68 & 0.03 & 0.24 \\
\hline The decisions made in my network are agreed among its members (I08) & 0.11 & 0.60 & 0.23 & 0.19 \\
\hline $\begin{array}{l}\text { The tasks in my network are carried out by teams including professionals from across all } \\
\text { participating schools (I07) }\end{array}$ & 0.10 & 0.50 & 0.26 & 0.33 \\
\hline In my network there are spaces of trust and mutual understanding among members (I20) & 0.51 & 0.47 & -0.06 & 0.22 \\
\hline I participate in the decision-making process of my network (I17) & 0.33 & 0.47 & 0.10 & 0.26 \\
\hline My network favors cooperation among its members (I11) & 0.26 & 0.47 & 0.26 & 0.21 \\
\hline School networks contribute to share resources among participant schools (I31) & 0.39 & 0.37 & 0.15 & 0.27 \\
\hline Participating in the network has improved my leadership skills (I06) & 0.17 & 0.00 & 0.75 & 0.22 \\
\hline My network helps me find solutions to problems that I face in my school (I05) & 0.18 & 0.05 & 0.70 & 0.22 \\
\hline
\end{tabular}


The members of my network understand that the work done is fundamental to improve school management (I03)

I feel very committed to the work we do in my school improvement network (I02)

The actions of my network are organized to address students' educational needs (I04)

The ideas that arise from my network have been implemented as actions or projects in my

school (I15)

The participation of the members of my network contributes to the work done in my school

(I16)

I use the knowledge generated in my network in my school (I14)

My network promotes that all members are creators of new ideas or projects (I01)

The topics discussed in my network are appropriate to the school context where I work (I10)

\begin{tabular}{llll}
0.08 & 0.18 & $\mathbf{0 . 6 4}$ & 0.27 \\
-0.03 & 0.31 & $\mathbf{0 . 6 1}$ & 0.27 \\
0.17 & 0.10 & $\mathbf{0 . 6 1}$ & 0.30 \\
0.30 & 0.08 & $\mathbf{0 . 5 6}$ & 0.18 \\
& & & \\
0.34 & 0.11 & $\mathbf{0 . 5 3}$ & 0.16 \\
0.13 & 0.31 & $\mathbf{0 . 5 3}$ & 0.18 \\
0.07 & 0.23 & $\mathbf{0 . 5 2}$ & 0.37 \\
0.06 & 0.47 & $\mathbf{0 . 4 1}$ & 0.22 \\
\hline
\end{tabular}


Table 3. Summary statistics for school network scales

\begin{tabular}{llllllll}
\hline Dimension & N items & N Obs & Mean & SD & min & max & Cronbach's $\alpha$ \\
\hline Networking & 13 & 1,721 & 4.80 & 0.95 & 1 & 6 & 0.97 \\
Professional capital & 9 & 1,722 & 5.10 & 0.86 & 1 & 6 & 0.94 \\
Networked Improvement & 10 & 1,723 & 4.88 & 0.95 & 1 & 6 & 0.96 \\
\hline
\end{tabular}


Table 4. Summary statistics by item

\begin{tabular}{|c|c|c|c|c|}
\hline 1,712 & 5.05 & 1.01 & $3 \%$ & $80 \%$ \\
\hline 1,713 & 4.99 & 1.03 & $4 \%$ & $78 \%$ \\
\hline 1,709 & 4.91 & 1.06 & $4 \%$ & $75 \%$ \\
\hline 1,573 & 4.87 & 1.09 & $5 \%$ & $74 \%$ \\
\hline 1,714 & 4.87 & 1.04 & $4 \%$ & $72 \%$ \\
\hline 1,717 & 4.84 & 1.09 & $5 \%$ & $73 \%$ \\
\hline 1,709 & 4.80 & 1.24 & $7 \%$ & $71 \%$ \\
\hline 1,711 & 4.78 & 1.12 & $6 \%$ & $70 \%$ \\
\hline 1,713 & 4.76 & 1.27 & $8 \%$ & $69 \%$ \\
\hline 1,704 & 4.74 & 1.18 & $7 \%$ & $68 \%$ \\
\hline 1,706 & 4.73 & 1.13 & $6 \%$ & $67 \%$ \\
\hline 1,548 & 4.67 & 21 & $8 \%$ & $68 \%$ \\
\hline 1,649 & 4.39 & 1.28 & $12 \%$ & $55 \%$ \\
\hline
\end{tabular}

The members of my network share their schools' practice to achieve our network objectives (I26)

Being in the network fosters a shared view for defining our network needs (I21)

In my network, we have shared responsibilities among its members (I22)

In my network there are leaders who help resolve differences in opinion and internal conflicts (I25)

The members of my network participate actively in the planned activities (I18)

My network facilitates the development of skills and professional development of its members (I29)

My network's agenda is developed based on the priorities and interests expressed by its participants (I23)

In my network we have created new knowledge by searching for solutions to shared issues (I30)

My interest to participate in network meetings has increased since the first meeting (I32)

In my network we evaluate how our work contributes to our schools' improvement (I27)

My network contributes to solve problems at our own schools (I28)

In my network there are norms for dealing with conflict that arise as a result of differences in opinions (I24)

My network established mechanisms and communications channels to link up with community actors and institutions (I19)

\begin{tabular}{|c|c|c|c|c|}
\hline & & & $\%$ & $\%$ \\
\hline Obs & Mean & $\begin{array}{l}\text { Std. } \\
\text { Dev. }\end{array}$ & $\begin{array}{l}\text { Strongly } \\
\text { disagree + } \\
\text { Disagree }\end{array}$ & $\begin{array}{l}\text { Strongly } \\
\text { agree + } \\
\text { Agree }\end{array}$ \\
\hline
\end{tabular}

\begin{tabular}{|c|c|c|c|c|c|}
\hline Dimension: Professional Capital & & & & & \\
\hline $\begin{array}{l}\text { In my network, the opinions of principals and curriculum } \\
\text { coordinators are equally respected than those of general } \\
\text { members (I09) }\end{array}$ & 1,712 & 5.29 & 0.96 & $3 \%$ & $88 \%$ \\
\hline $\begin{array}{l}\text { In my network, I feel I participate at the same level as other } \\
\text { members (I13) }\end{array}$ & 1,717 & 5.20 & 0.99 & $3 \%$ & $85 \%$ \\
\hline $\begin{array}{l}\text { In my network, I feel there is trust to freely express my } \\
\text { perceptions and disagreements (I12) }\end{array}$ & 1,718 & 5.19 & 1.03 & $3 \%$ & $83 \%$ \\
\hline $\begin{array}{l}\text { School networks contribute to share resources among } \\
\text { participant schools (I31) }\end{array}$ & 1,714 & 5.18 & 0.97 & $3 \%$ & $83 \%$ \\
\hline
\end{tabular}


The decisions made in my network are agreed among its members (I08)

$\begin{array}{ccccc}1,712 & 5.12 & 1.04 & 4 \% & 82 \% \\ 1,717 & 5.07 & 1.02 & 3 \% & 80 \% \\ 1,711 & 5.01 & 1.03 & 3 \% & 77 \% \\ 1,705 & 4.95 & 1.14 & 5 \% & 77 \% \\ 1,699 & 4.89 & 1.12 & 5 \% & 73 \%\end{array}$

My network favors cooperation among its members (I11)

In my network there are spaces of trust and mutual understanding among members (I20)

The tasks in my network are carried out by teams including professionals from across all participating schools (I07)

I participate in the decision-making process of my network (I17)

\begin{tabular}{|c|c|c|c|c|c|}
\hline \multicolumn{6}{|l|}{ Dimension: Networked Improvement } \\
\hline $\begin{array}{l}\text { The topics discussed in my network are appropriate to the } \\
\text { school context where I work (I10) }\end{array}$ & 1,721 & 5.18 & 1.00 & $3 \%$ & $84 \%$ \\
\hline $\begin{array}{l}\text { I use the knowledge generated in my network in my school } \\
\text { (I14) }\end{array}$ & 1,716 & 5.08 & 1.02 & $4 \%$ & $81 \%$ \\
\hline $\begin{array}{l}\text { I feel very committed to the work we do in my school } \\
\text { improvement network ( } 102)\end{array}$ & 1,721 & 5.07 & 1.09 & $5 \%$ & $80 \%$ \\
\hline $\begin{array}{l}\text { The members of my network understand that the work done } \\
\text { is fundamental to improve school management (I03) }\end{array}$ & 1,713 & 4.94 & 1.13 & $5 \%$ & $75 \%$ \\
\hline $\begin{array}{l}\text { My network promotes that all members are creators of new } \\
\text { ideas or projects }(\mathrm{I} 01)\end{array}$ & 1,716 & 4.86 & 1.21 & $7 \%$ & $74 \%$ \\
\hline $\begin{array}{l}\text { The actions of my network are organized to address students' } \\
\text { educational needs (I04) }\end{array}$ & 1,716 & 4.85 & 1.17 & $6 \%$ & $71 \%$ \\
\hline $\begin{array}{l}\text { The participation of the members of my network contributes } \\
\text { to the work done in my school (I16) }\end{array}$ & 1,706 & 4.78 & 1.08 & $5 \%$ & $70 \%$ \\
\hline $\begin{array}{l}\text { My network helps me find solutions to problems that I face } \\
\text { in my school (I05) }\end{array}$ & 1,7 & 4.76 & 1.15 & $6 \%$ & $67 \%$ \\
\hline $\begin{array}{l}\text { The ideas that arise from my network have been } \\
\text { implemented as actions or projects in my school (I15) }\end{array}$ & 1,705 & 4.70 & 1.11 & $6 \%$ & $67 \%$ \\
\hline $\begin{array}{l}\text { Participating in the network has improved my leadership } \\
\text { skills (I06) }\end{array}$ & 1,707 & 4.6 & 1.23 & $9 \%$ & $64 \%$ \\
\hline
\end{tabular}

Note: each item has a six-point scale, from strongly disagree $(=1)$ to strongly agree $(=6)$. 
Table 5. Subgroup analysis for each dimension, by school performance categories

\begin{tabular}{lccc}
\hline & \multicolumn{3}{c}{ Dimensions } \\
\cline { 2 - 4 } Performance categories & $\begin{array}{c}(1) \\
\text { Networking }\end{array}$ & $\begin{array}{c}(2) \\
\text { Professional } \\
\text { Capital }\end{array}$ & $\begin{array}{c}(3) \\
\text { Networked } \\
\text { Improvement }\end{array}$ \\
\hline High (=1) vs insufficient performance & 0.127 & 0.170 & -0.033 \\
$\quad$ primary schools & $(0.197)$ & $(0.159)$ & $(0.194)$ \\
Observations & 210 & 210 & 210 \\
R-squared & 0.08 & 0.14 & 0.07 \\
& & & \\
High (=1) vs insufficient performance & -0.440 & -0.231 & $-0.570^{*}$ \\
$\quad$ secondary schools & $(0.245)$ & $(0.187)$ & $(0.243)$ \\
Observations & 93 & 93 & 93 \\
R-squared & 0.21 & 0.26 & 0.23 \\
\hline
\end{tabular}

Notes: All models control for school rurality, school type and region. Standard errors in parentheses. $* * \mathrm{p}<0.01, * \mathrm{p}<0.05$ 
Table 6. Subgroup analysis for each dimension, by school and network roles

\begin{tabular}{|c|c|c|c|}
\hline & \multicolumn{3}{|c|}{ Dimensions } \\
\hline School and Network roles & $\begin{array}{c}\text { (1) } \\
\text { Networking }\end{array}$ & $\begin{array}{c}(2) \\
\text { Professional } \\
\text { Capital } \\
\end{array}$ & $\begin{array}{c}\text { (3) } \\
\text { Networked } \\
\text { Improvement }\end{array}$ \\
\hline $\begin{array}{l}\text { Principal }(=1) \text { vs curriculum } \\
\text { coordinator }\end{array}$ & $\begin{array}{c}0.141 \\
(0.100)\end{array}$ & $\begin{array}{c}0.133 \\
(0.080)\end{array}$ & $\begin{array}{c}0.094 \\
(0.098)\end{array}$ \\
\hline Observations & 313 & 313 & 313 \\
\hline R-squared & 0.28 & 0.29 & 0.23 \\
\hline $\begin{array}{l}\text { Rural }(=1) \text { vs urban school } \\
\text { principals }\end{array}$ & $\begin{array}{c}0.018 \\
(0.091)\end{array}$ & $\begin{array}{l}-0.036 \\
(0.080)\end{array}$ & $\begin{array}{c}0.104 \\
(0.091)\end{array}$ \\
\hline Observations & 687 & 687 & 688 \\
\hline R-squared & 0.17 & 0.17 & 0.16 \\
\hline $\begin{array}{l}\text { Network coordinator }(=1) \text { vs } \\
\text { network member }\end{array}$ & $\begin{array}{c}0.115 \\
(0.065)\end{array}$ & $\begin{array}{c}0.041 \\
(0.059)\end{array}$ & $\begin{array}{l}0.169 * * \\
(0.065)\end{array}$ \\
\hline Observations & 1,672 & 1,673 & 1,674 \\
\hline R-squared & 0.11 & 0.12 & 0.10 \\
\hline
\end{tabular}

Notes: All models control for gender, years participating in the SIN, attendance to SIN meetings, involvement in the 2017 SIN work plan, years of experience in the school educational system, school type and region. Standard errors in parentheses. ${ }^{* *} \mathrm{p}<0.01,{ }^{*} \mathrm{p}<0.05$ 